The University of Maine

DigitalCommons@UMaine

Child Development and Family Relations Faculty

Scholarship

Child Development and Family Relations

Summer 2011

\title{
The Persona Doll Project: Promoting Diversity Awareness Among Preservice Teachers Through Storytelling
}

Mary Ellin Logue

University of Maine - Main, mary.logue@maine.edu

V. Susan Bennett-Armistead

University of Maine - Main, susasn.bennett-armistead@maine.edu

SooJoung Kim

University of Maine - Main

Follow this and additional works at: https://digitalcommons.library.umaine.edu/chf_facpub

Part of the Pre-Elementary, Early Childhood, Kindergarten Teacher Education Commons

\section{Repository Citation}

Logue, Mary Ellin; Bennett-Armistead, V. Susan; and Kim, SooJoung, "The Persona Doll Project: Promoting Diversity Awareness Among Preservice Teachers Through Storytelling" (2011). Child Development and Family Relations Faculty Scholarship. 1.

https://digitalcommons.library.umaine.edu/chf_facpub/1 


\title{
The Persona Doll Project: Promoting Diversity Awareness Among Preservice Teachers Through Storytelling
}

\author{
Mary Ellin Logue \\ V. Susan Bennett-Armistead \\ SooJoung Kim \\ University of Maine \\ Corresponding author: \\ Mary Ellin Logue \\ College of Education and Human Development \\ 112 Merrill Hall \\ University of Maine \\ Orono, ME 04469 \\ (207) 581-2726 \\ mary.logue@umit.maine.edu
}

The Persona Doll Project describes an experiential intervention with undergraduate preservice teachers designed to increase awareness about diversity and apply this awareness to curriculum planning and advocacy for children. Sixty-three undergraduate students in a social studies methods class were each assigned a persona doll for the semester whose background differed from their own. Each was charged with becoming the advocate for the child, represented by the doll, by telling informed stories that would help other students better understand a level of diversity beyond what they knew from their own lives. Students heightened awareness of their own assumptions through narrative, inquiry and reflection and used that knowledge to critically analyze teaching practices that promote inclusion or exclusion. Students reported increased confidence for working in diverse communities. One goal of teacher education programs is to prepare teachers to work with students from racial/cultural/linguistic backgrounds other than their own. This article provides one example of how to address this important goal.

Keywords: early childhood education, diversity, anti-bias education, perspective taking, teacher education, storytelling

\section{Introduction}

After a semester of working with persona dolls in a social studies methods class, a student reflected on changes in her thinking about children and families. "When I learned that Heather's (a persona doll) mother was 16 when she was born and that her family experienced generational poverty and lived in a subsidized apartment, my judgments popped up. Lena's (a fellow student in the class) stories and advocacy helped me put those judgments aside and see Heather...brilliant and wonderful. We may not be able to prevent our judgments but we can think them through... and change them."

A major goal of diversity education in teacher education programs is to prepare all 
teachers to work with the full range of children they will encounter. The population of students in public schools becomes increasingly diverse while the population of preservice teachers enrolled in the nation's colleges and universities continues to be largely White and middle class with little exposure to people from different ethnic, linguistic or social status different than themselves (Causey \& Armento, 2000). The challenge for teacher educators then, is to find effective ways to help these young teachers reflect on their own cultural experiences and biases in ways that open dialogue about children from backgrounds that are unfamiliar to the students.

The Persona Doll Project described in this article, reports a curricular intervention with a class of preservice teachers in a rural, northeastern state. The project was designed to: increase preservice teachers' awareness of their beliefs, attitudes and values as they relate to teaching young children; promote appreciation for diversity through experiences that promote perspective taking, and the ability to view educational practices and experiences through the eyes of children; and finally, to develop or strengthen advocacy skills and awareness of the socio-political challenges some children face in schools.

This article will present the rationale and background for project, a detailed description of the project's implementation, and a summary of its impact on preservice teachers' beliefs and attitudes. In this article, persona dolls are indicated with an initial asterisk symbol (*) and then lower case throughout. Preservice teachers' pseudonyms are in CAPS.

\section{Background for the Project}

Since 1979, teacher education programs have been expected to prepare teachers to work with diverse learners (National Council for
Accreditation of Teacher Education, 2002). The results of these efforts have met with mixed results (Sleeter, 2001). In some cases, teacher knowledge increased and attitudes toward diverse learners changed but in other cases, negative attitudes persisted or intensified. The background and attitudes preservice teachers bring to a class that addresses issues of diversity affect the outcomes of the class. Preservice teachers who begin the study of diversity with an attitude of openness toward groups other than their own are more likely to become more sensitive to the learning needs of diverse students, while those holding unfavorable attitudes at the beginning become less favorable (Kagan, 1992).

There are several reasons why attempts to change preservice teachers' attitudes have failed. Many educators treat diversity as a euphemism for race and therefore miss the opportunities to discuss differences of culture, language, socioeconomic status, ability and disability and gender. Teachers with little exposure to diversity are vulnerable to subtle forms of discrimination. Dysconscious racism, involves purposefully overlooking differences and accepting inequalities as a given. Examples of dysconscious racism are beliefs that teachers should treat all children the same, and that fairness is equivalent to the same treatment regardless of the child's need or privilege (Ladson-Billings, 1994). Other subtle barriers to attitude change include: optimistic individualism, a belief that with hard work and individual effort, any child can succeed (McCall, 1995; Nieto, 1998); a belief in absolute democracy, a belief that "kids are kids" and that "good" pedagogy is equally effective for all students (Nieto, 1998); naïve egalitarianism, belief that everyone should be treated equally and have access to equal resources, and colorblindness, a belief held by preservice and practicing teachers alike to deny the impact of 
race and privilege on children's preparedness and learning (Causey, Thomas, \& Armento, 2000).

\section{Approaches to Teaching about Diversity}

Diversity education that will change attitudes and teaching practices helps candidates understand themselves and how their own individual family and ethnic cultures affect their learning and problem solving skills, and in turn, how they can use each child's unique background to support teaching and learning (Hyun, 2003). While there is general agreement among teacher educators about the desirable dispositions and attitudes teachers need to effectively work with diverse student groups, there are no clear guidelines for how to best foster these qualities. Research suggests two promising strategies for promoting critical thinking about diversity that go beyond a surface knowledge of different cultural groups.

Autobiography and case studies.

Autobiography and case studies are effective tools in promoting preservice teachers' thinking about their own beliefs (Clark, 2000; Xu, 2000). These experiences provide opportunity to practice and reflect, and to use language to address the needs of individuals within the context of the group. When these experiences are shared with others, the collaboration context for building communities of learners (Moran, 2002). Xu (2000) found increased appreciation for cultural differences among preservice teachers who integrated case study and application to classroom practice over the course of a semester.

Storytelling and written narrative. The use of narrative as a tool in teacher education has been increasing in recent years (Doyle \& Carter, 2003; Munby, 2001). Munby's research suggests that while story is a fundamental way of human knowing, novice teachers are likely to fall back on what they know about teaching (i.e., typically their own experiences as students) in storytelling. Elbaz-Luwisch's Coexistence Workshop, uses personal storytelling to help Arab and Israeli students identify areas of commonality, connection and shared concern, and to better understand the perspectives of the other group (Elbaz-Luwisch, 2001). Classes such as Elbaz-Luwish's provide opportunity for students to share their personal stories and viewpoints in a forum facilitated by teachers. Elbaz-Luwish suggests that these workshops typically rely on focusing on supporting personal relationships among members of the different groups, or focusing on creating a collective identity, using the group itself to confront injustice. These workshops meet twice weekly for 90 minutes over the course of a semester. These authors speculate that the frequency and intensity of the interaction among participants in the Coexistence Workshop may be a factor in the workshops' success.

Shared written narrative has also shown effectiveness in helping students examine their implicit attitudes and values. Bolton (2006) identified increased professionalism when small groups of students read and reflected on both fiction and non-fiction narratives. The emotional power of stories can promote reflection and perspective taking among preservice teachers as one's story may trigger others' memories of similar feelings in situations or ways problems were faced or solved even when the stories were quite different (Conle et al., 2000).

While multicultural awareness courses have shown little effectiveness in changing preservice teachers' beliefs about diversity (Sleeter, 2001), or in promoting critical thinking about the school-related challenges children from diverse backgrounds face (McIntosh, 1988; Sleeter, 1995), the use of perspective taking experiences including, case studies, sharing autobiographies and various forms of narrative show promise 
(Boling, 2007). It is on this body of research the Persona Doll Project is constructed.

\section{Project Design}

Theoretically, this project is rooted in Selman's theory of social perspective taking ability (1980) and related research showing that "good" perspective takers display empathy and compassion and are better at thinking of effective ways to handle difficult social situations that reflect multiple perspectives (Berk, 1994; Eisenberg, 1987). Perspective taking involves coordinating one's own view and that of another with the aim of promoting both cognitive development and social reasoning.

\section{Participants}

Early Childhood Education undergraduate students in a public, northeastern university enrolled in a required social studies curriculum class prior to their practicum and student teaching. This writing-intensive class averages 15-17 students each semester. This paper summarizes four semesters from the Persona Doll Project, incorporating the experiences of 63 students. Classes were held twice a week for 90 minutes for fifteen weeks. All students identified as Caucasian. With the exception of one woman in her 50's, all students were in their early 20's. All except one grew up in small, rural towns. All reported having been reasonably successful in school. All envisioned themselves teaching young children who were eager to learn, respectful and "well behaved." All had some personal exposure to children with disabilities but only two students had an ongoing friendship with a person from a different racial or linguistic background. When discussions about "successful" and "unsuccessful" students occurred during the first week of classes, students tended to place the blame for school difficulty on either the children or their parents.
Most students were prepared to make accommodations for a child with a physical disability, but felt little conflict about excluding a child with challenging behavior from the classroom or sending a child to the library if her religious principles forbade her from participating in an activity most children celebrated. Given the changing demographics of the state and the nation, the classrooms in which these teachers would eventually teach are likely to be much more diverse than the ones they inhabited as children.

\section{Documenting the Students' Learning Through the Persona Doll Project}

Across four fifteen-week semesters of a social studies methods class, the first author collected data in the form of weekly written reflections, interviews with students from previous semesters who were student teaching or in their first teaching positions, written copies of persona doll stories, and notes taken during class discussions. Reflective writing prompts and autobiographical assignments were also collected and analyzed to show change over time for individual teachers and to understand common issues and concerns. Using constant comparative methods for analyzing data (Glasser, 1965), the authors discovered how preservice teachers construct and re-construct ideas for teaching an inclusive class.

\section{Structure of the Persona Doll Project}

This project, enacted over four semesters across three years, had several components. The next sections will illustrate the components of the program and their implementation. These components include the persona dolls themselves, the assignments and activities associated with the dolls, resources provided and accessed to promote the students' understanding of the dolls and their situations, guest speakers, 
and the ritual associated with making the dolls a real part of the class.

The dolls. Persona dolls have been used with children as a tool for promoting anti-bias thinking and attitudes (Derman-Sparks, 2010; Whitney, 2002). On the second day of class, each student was assigned a persona doll and a brief description of the dolls' circumstances. The course teacher and first author developed the doll descriptions modifying the Derman-Sparks (1989) and Whitney (1999) guidelines. Characteristics of the dolls reflected characteristics of children teacher candidates might meet in their future internships or teaching careers. These 8-inch cloth dolls, purchased from a school supply company, were racially diverse, male and female, with and without overt disabilities. The dolls were randomly assigned to students. The expectation was for each student to learn as much as they could about the doll's life in and out of school, by researching the doll's background and examining teaching practices through the perspective of their doll in order to identify how these practices support or hinder the doll's development. Doll descriptions are included in Appendix A. Some dolls lived in low-income families and another was wealthy, one was deaf, one had Cerebral Palsy, and another had Tourette's Syndrome. One doll had been diagnosed with Attention Deficit Disorder and Oppositional Defiant Disorder and another with Asperger's Syndrome. One family was conflicted over a potential cochlear implant while another struggled with the child's cancer treatment. Some dolls lived with single mothers, some with fathers and some in foster care. The dolls had different religious backgrounds. One was Jewish, one was Muslim, several were Christian, and one was a Jehovah Witness. The dolls attended class throughout the semester, sitting with their teachers.

Assignments and activities. Using a strategy demonstrated in Starting Small (1997) to build community and trust, each student was asked if she had "news" to share. The ritual of telling "news" also became the forum to explore teaching strategies that might work with this "class" of children and also for each advocate to inform theirs about the results of her/his research on characteristics of the doll. The "news" was brief, taking no more than the first 10 minutes of class. For example, Janella's* advocate might report that janella scribbled on the table and lost recess yesterday. She finished her math work before everyone else and had to wait for the whole class to finish before moving to another lesson. Subsequent "news" by this teacher advocate reported on different strategies the teacher could use to support janella (a child gifted in math) in the classroom based on her advocate's research on best practices for teaching children with intellectual gifts. The preservice teachers were welcome to share any news about themselves if they chose. In addition to the daily news, teacher candidates, in turn, prepared and shared a persona doll story following guidelines described by Trish Whitney (2002). These more fully developed stories presented, in an open-ended way, real challenges faced by children like their persona doll in school and at home. The issues had to reflect the thinking and concerns of young children and to require the audience to help the doll solve the dilemma posed without pushing for a "correct" resolution (Edwards, Logue \& Russell,1983). The goals of the doll story vary. The stories could give new information, undo incorrect information or stereotypes, introduce new emotional vocabulary to teach skills for handling emotions, or teach a prosocial skill. The stories pose an issue the persona doll-child might experience in a classroom and provide opportunity for the group to solve the problem by generating a range of solutions. The storyteller does not judge the responses but does summarize them. The stories could address difference but only as one dimension of a child's 
life. For example, one story about Carlos* presented his concern about losing his hair because of chemotherapy and fear of being teased, but another addressed how angry he got when his brother cheated playing cards. These stories helped the preservice teachers develop storytelling skills but also confidence in talking about difficult issues and refraining from judgment when trying to elicit others' opinions. They also drew attention to the many ways we, as a group, were both the same and different. After presenting the story, class members gave feedback on ways to heighten the conflict in the story, pace the story and ask good questions. After this pilot test, the teacher candidate told the story to children in our laboratory school preschool and reported back to the class about children's ideas related to their persona doll. These discussions helped illuminate children's thinking about social and cultural issues and helped the next storyteller refine her questions for the next story.

Resources. Each teacher candidate was given contact information for a community consultant willing to share about his or her experience and expertise. Candidates communicated with their consultants by phone or email and some were even invited to the consultant's home for indepth conversation. Use of community consultants was completely optional. Additionally, the class instructor set up an electronic folder where resources for each doll could be collected and shared.

Guest speakers. As in many classes like this, several guest speakers who share characteristics with the persona dolls visited the class to share their stories and expertise. Different from other classes however, these speakers were there not to deliver all the information about the focal characteristics but to serve as one of many resources that would inform students' perceptions of the children and their needs.
Ritual. Critical to the project design is the consistent routine established for the classes. Ford \& Dillard ( 1996) suggest that process of becoming multicultural is a personal, recursive process. Repeated opportunity to practice new skills, many of which are uncomfortable, in a safe, predictable environment allowed preservice teachers to build trust with one another and confidence in their developing narrative skills.

\section{What We Learned}

The goals of the Persona Doll Project are threefold: increase preservice teachers' awareness of their own beliefs, attitudes and values as they relate to teaching young children; promote appreciation for diversity through experiences that deepen perspective taking, and the ability to identify effective and ineffective teaching practices through the eyes of the diverse class of "children." The course teacher systematically analyzed written assignments and field notes to identify themes indicating changes in attitudes, beliefs and awareness. Twice during the semester, students were asked to reflect on their own learning and the themes derived from these reflections were shared and discussed by the class as a way of promoting reflective practice. Outcomes from each goal are reported separately.

\section{Identifying One's Own Biases, Beliefs and}

Attitudes through Reflection and Narrative

Through doll stories, speakers and reflective writing, preservice teachers reflected on their own experiences and in some cases, took new interest in their own heritage. In the first example, the preservice teacher, identifying with a persona doll (not her own), makes a connection between the doll's experience and her own. In so doing, she also takes the perspective of her mother, an important step in learning to intentionally work with parents and family members. 
I understand Heather* from my own life, as my mom was young when I was born. Unlike heather, I still saw my dad but there were many, many times when my mom and nana would go to my parent/teacher conferences. I wonder if teachers judged my mom the way they did heather's mom. Carrying the weight of others' biases can be hard on parents and kids.

Guest speakers who share characteristics with persona dolls helped inspire many preservice teachers to reflect on their own family heritage when previously, they thought they had none.

I was deeply moved by Karen's visit (guest speaker who spent her career as a White teacher working with Native American children). I have never really been overly interested in my heritage. However, Karen inspired me to really think about my Native American background. One of the things I realized that I hadn't thought about before is how recent this history really is. We were never close to my maternal grandfather. He died when I was rather young but he was sent to a boarding school. It never struck me that perhaps my own family members were experiencing the things Karen talked about at boarding schools, etc. I don't know how I compare to most Americans, but I basically thought that we just came in and took over the land and that was the end of the story. What I didn't realize is that it goes much deeper than simply taking land. How much of my grandfather's misery and my mother's pain is tied to that history?

Through the doll stories, we had almost daily opportunity to examine how different perspectives could raise conflicts in schools and classrooms and the important role teachers play in promoting understanding across perspectives. In the following example, a preservice teacher begins to separate out personal belief from teacher belief.
I never realized how many ways there are to define "normal." Teachers need to understand their own backgrounds so they can be conscious of the way they were brought up and what they perceive as "normal." Personally, I have a hard time not judging others' faiths but I know now that to be the teacher I want to be, I have to suspend that judgment and learn from the families whose faith is different than mine.

Exposure to perspectives different than one's own served as a catalyst for reflective practice. As preservice teachers became more knowledgeable about their own persona dolls, appreciating the areas of similarity and difference to their own childhood experiences, their eagerness to share their learning about their persona dolls as well as the other dolls in the class increased.

Promoting Appreciation for Diversity by Increasing Perspective Taking: Seeing School through the Eyes of Others

The depth of information conveyed through stories deepened as the preservice teachers became more knowledgeable about their dolls and more comfortable telling stories. CINDY's doll Billy* has Aspergers Syndrome and is very focused on facts related to NASCAR. CINDY actually spent Sunday afternoons watching NASCAR races in order to give credibility to billy "news." She also communicated regularly with her community consultant, a first grade teacher in an inclusive classroom whose own son has Asperger's Syndrome to learn effective strategies to work support billy's learning. She even bought breakfast cereal to get the free NASCAR car for billy to share at "news." Her classmates appreciated the information and opportunity to discuss accommodating a child with Asperger's Syndrome in the classroom.

I learned a lot about billy from our class discussions. We always tied NASCAR into our 
everyday discussions. I learned so much about Asperger's Syndrome. I was amazed at how much I didn't know. CINDY always seemed to have new information to bring to class. I feel confident I could teach math, science or literacy to a child like billy through his interests. We came to understand and really care about every doll. By tying our research into stories about our dolls, we educated each other about so much more than specific disabilities, religions or family structure.

The preservice teachers genuinely cared about the dolls and the real children they represent. It is not possible to tell from these data whether students introduced to the characteristics of children with Asperger's Syndrome would go into the depth these students did when planning across the curriculum. These pre-service teachers clearly took the perspective of their dolls and through this, began to develop curriculum in creative, new ways. For example, Pierre's* and Mei's* teacher-advocates spent so much time outside class talking about their dolls and their own efforts to involve families of English Language Learners, that at dinner, a friend asked in earnest if pierre's family knew that the Pope was coming to America? The friend had no idea that pierre and mei were dolls and not children.

The two dolls who presented the greatest challenge to the preservice teachers' comfort levels were Toby*, the doll with serious behavior challenges and Omar*, the doll who had been a refugee from Somalia. In both cases, having a guest speaker share his/her experience and answer questions brought the doll stories to a deeper level.

Tommy's talk really influenced my thinking. When Tommy told us his story, he even said, "I was just like that kid (toby)." What I learned from Tommy is not to put labels on the child that acts out. The child may just need to be comforted and to know that someone cares. His life seemed like the total opposite of mine. In school I never got along with the kids that acted out and I never understood how they could do that in school. I now know that there could be some underlying problems or stresses, which make a child, act out. I want to teach differently than what I saw.

Hard as it was for most students to imagine strength, courage and a sense of humor one could have in the face of the violence and loss toby experienced before meeting Tommy, it was equally hard to imagine why anyone who had been a refugee might miss their homeland. Without the human face to inform the dolls, we might have perpetuated static attitudes.

I always assumed that anyone who came to America as a refugee would be totally glad to be here. Fatima (guest speaker) spoke about feeling that she was torn between two places. In her home country, she is seen as an American, and here is seen as a foreigner. Young children may not be able to articulate that even if they feel it. As a teacher, I need to look at that prejudice of mine.

Even students with some exposure to a different culture may not have considered the perspective of the newcomer to her school.

I had a small bit of knowledge of the Muslim religion before I met Fatima or heard omar's stories. I went to school with a girl for a couple of years who was Muslim. Miriam seemed to be quite Americanized, however, she fasted during Ramadan but it wasn't celebrated or taught, but hidden instead. M. dressed as an American girl would. She didn't pray at noon. After hearing Fatima talk, when I look back, I wonder if she chose these behaviors or followed these traditions because she might receive negative attention. Was Miriam as "Americanized" as we thought or was she trying to protect herself from 
disapproval? It saddens me to think that, like Fatima, she might have had to run to the bathroom at noon to pray? As a teacher, I want our classroom to be safe and accepting for all children.

The ability of teachers to take the perspective of their students is necessary in order to critically analyze traditional school practices, remove barriers that such practices impose on children, and to advocate for social change to address the systemic barriers.

Analyzing Effective and Ineffective Teaching Practices through the Eyes and Experiences of

\section{Persona Dolls}

The language we use to discuss children and families shapes our own thinking (Nieto, 2009). Preservice teachers reflected on their own thinking and the impact of language on children's learning through their shared stories and those of our guest speakers. Guests speaking about adoption introduced People-First Language, a convention originating in the disability community where the person's humanity is mentioned before the disability. Rather than speaking about the "autistic boy", the speaker would refer to the "boy with autism." The preservice teachers were challenged to reflect on their own language and language they'd assumed was "normal" from the perspective of the children being described. This skill, more than any specific skill taught in the class, had the greatest impact on the students' language and writing.

"People-first" language made a huge impact on me. When they (our guests) were asked which of their children were their "real" children, they said, "All of our children are real." WE ARE ALL REAL! I have found myself talking about "adopted children or disabled children" but I always hear it when someone says that now. These children are
CHILDREN first. We need to be mindful of our language. It's powerful.

Additionally, during the course of one semester, students became aware of how other cultures use language differently than their own culture might. One of the dolls that semester had been named Mohammed, to reflect and honor the frequency of that name used in Arabic communities. Through a news story that highlighted the strife of a British teacher teaching in a Muslim community in Africa, the students learned that naming a doll Mohammed was actually an insult to that community (nonhuman entities cannot be named after the Prophet). As a response, the students agreed to change Mohammed's name to Omar. The richness of the discussion and opportunity to address cultural sensitivity would likely not have come up but for our ignorance being confronted by a media story of which the students became aware and everyone's willingness to discuss a sensitive issue.

Examining school practices through the eyes of our persona dolls prompted analysis of how teachers can plan environments, schedules and curriculum in ways to help all children succeed. Searching for solutions that worked for the whole class was harder than planning for the majority and having carlos watch when the activity involved running or leaving josie out if her interpreter wasn't in the room. Teacher candidates began to think about the content in pictures on the wall, books in the classroom library, how and when they communicated with families, what they celebrated and how they guided children's behavior. Every child belonged in this class. Every teacher was committed to creating and maintaining a classroom environment where everyone succeeded.

Tommy's talk helped me realize that children like toby need places to go to calm down and 
they need time to get their energy out or their anger can take over. I especially like the idea of the Peace Corner used in Montessori programs. It's not a "time-out" but a place to go to selfregulate or to work out a disagreement with another. Couldn't we all use that? Another preservice teacher wrote in her journal:

I was horrified to hear Aifan talk about having to go into the bathroom with her Muslim friends to pray during the day. That's gross! If we put our Peace Corner facing east, omar could just quietly use it to pray without it being a big deal.

At the end of the semester when preservice teachers reflected on how the persona dolls' stories influenced their intentions as teachers, many of them drew a line between how they were educated and how they planned to teach.

If I teach the way I was taught, I would send carlos to the nurse's office when he got tired, send toby to the principal when he got angry and damien to the library whenever we celebrated a holiday. Why not create a Peace Corner where tired children can rest and angry children can regroup. Why not have gatherings everyone can be part of rather than drawing negative attention to those whose beliefs are different from the majority. It is our job to create communities where everyone belongs.

It is not enough to identify effective and ineffective practices. In order to promote those practices that support each doll's learning and development, teacher candidates practiced writing letters to their doll's next teacher, highlighting the strengths and promoting teaching practices that support the doll's learning. Their writing reflects a strong commitment to inclusive education evidenced in the examples below. They recognized that, without advocacy, many of the subtle successes of this semester would not be carried forward. janella's talents could be overlooked without a teacher to advocate for her. Even I found myself more concerned with her bossiness and fitting in than about her extraordinary interest in math. I learned through my research, that minority children are under-represented in gifted and talented programs. I do NOT want that to happen to janella.

Damien*'s advocate wrote passionately about teaching attitudes and practices she expects from a teacher.

I want the teacher to know that damien has cerebral palsy but that it is a mild form that only affects his speech and gait, NOT his intelligence. I want the teacher to also have some idea of what we have done in my classroom to make it work for damien. I also want the teacher to know that damien's family is Jehovah Witness so she/he needs to think about classroom celebrations differently. Excluding damien would NOT be acceptable.

\section{Limitations and Cautions}

This description of the Persona Doll project addressed learning that occurred during the course of a semester-long class. It is important to follow these preservice teachers into their student teaching experiences and early teaching experiences to see if the simulation has any lasting impact on behavior. We will continue to do so. Persona dolls were useful tools, making concrete the barriers faced by many children in schools. Their daily presence in each class created a reminder to inform discussion not only on their own experiences as students, but also on their dolls' experiences. The essence of the project though, is in the storytelling and reflective writing. As Waldorf educators plan every lesson to include "the head, the heart and the hands" (Petrash, 2002), educators, using 
ideas from this project, must help the preservice teachers care about the impact of language, instructional practices and accepted routines on individuals. The authors/class teachers are well connected in the community and able to secure guest speakers easily. Not every instructor will have these connections but every community has experts and the students themselves are valuable resources. Networking to locate a few key speakers is highly encouraged, especially for the areas where preservice teachers' bias is most strongly evident.

When implanting the Persona Doll Project, there is a risk for an inexperienced teacher to inadvertently reinforce negative stereotypes. To begin the project, we recommend creating persona doll profiles based on characteristics of children the teacher knows or has known or for which community consultants exist. For example, while we are not authorities on Asperger's Syndrome, we know some children with it. When a student told a persona doll story about billy feeling a little under the weather because of his Asperger's Syndrome and so he missed Cub Scouts, the teacher gently suggested, "How does Asperger's Syndrome make a child feel under the weather? Could you report back to us next week?" The next week, the student reported, "I was wrong about billy last week. I hadn't really looked into Asperger's Syndrome much when I said he missed Cub Scouts because of his Asperger's Syndrome. It's not something you catch like a cold. It's a difference in his brain that affects how he sees the world and interacts with others. Stay tuned...I'll have more stories!"

A teacher's willingness to learn about diversity and difference and not shy away from difficult conversations is key to the success of this project and to children's social and academic success in schools. Admitting one's own limitations and joining students in learning more about the children in a class can diminish

Volume 6 Number 2 discomfort and encourage genuine conversation (Cowhey, 2006, Paley, 1996). Guest speakers and community consultants educate the teacher as well as the student.

For example, one student asked of the parents of the family who was expanded through adoption, "Why didn't you just adopt a child from the United States?" Both of their children were adopted internationally. The ensuing discussion allowed the parents to confront the view that it's somehow un-American to adopt from other countries and that children everywhere need forever families. It also allowed for a glimpse at the family's personal history with disrupted adoption. The complexity of adoption and the decisions that affect the plans families make would not have come to light had this student not asked her question.

By preparing the guest speakers in advance with some of the questions students might ask, teachers can assist the discussion to go beyond the surface to the deep, personal issues involved. Of course that necessitates selecting guest speakers willing to share their personal stories. Again, the novice instructor will want to sensitively foster these relationships with guest speakers to maximize both the benefit to students and the respectful handling of the guests.

\section{Discussion}

The doll stories informed by student research, guest speakers and community consultants provided opportunity for preservice teachers to examine their own beliefs, take the perspective of one child and coordinate that with a class of children, and to develop tools for advocacy. While initially, many students viewed others whose perspectives differed from than their own with fear or negative judgment, by the end of the semester, everyone could describe the strengths of every doll and provide advice for how that 


\section{Social Studies Research and Practice}

http://www.socstrp.org

doll's needs would be best served in a classroom. The concepts put forth by Gonzalez, Moll \& Amanti's (2005) for identifying the vast "funds of knowledge" available to each child through daily interactions with family members developed for the dolls through story. As Schussler, Stooksberry and Bercaw (2010) concluded in their disposition study, "For candidates to use multiple perspectives to reflect on teaching situations and achieve parity in focusing on students and the self requires time and sequential scaffolding across a program" ( $\mathrm{p}$. 361). The work begun in the Persona Doll Project, supporting teacher candidates' dispositions to balance their own self-awareness of their own cultural assumptions with the needs of diverse learners, must be continued in their internship experiences. Ideally, the methods teachers would also be field supervisors. Regular and ongoing communication among field supervisors and methods teachers is, at least, important to foster lasting dispositions among teacher candidates.

While readings and guest speakers addressed issues of social inequality, there was almost no evidence from any reflective writing, oral stories or case studies discussing the role of teachers in addressing societal barriers to opportunity. The preservice teachers are convinced that THEY will make a difference in creating equal opportunity for the children in their classrooms. Within the sanctuary of the classes they teach, children will be equal and valued. This overconfidence could be problematic if they face challenges beyond their skill sets to solve. Student teaching supervisors and mentors can support the struggle all teachers face in creating equity for children. Certainly, teaching about social inequity and institutional barriers to opportunity is important in any diversity class. It may be too much for one class, however. The over-confidence we see may be a developmental progression in teachers' appreciation for diversity as they expand their appreciation for diversity through increased perspective taking ability. If increased perspective taking leads to increased teacher efficacy and increasing levels of advocacy, the critical thinking necessary to analyze the impact of societal injustice on the dolls could be the next stage of development in the process of becoming an inclusive teacher. More research and theory building is necessary.

Many courses work to modify students' attitudes and beliefs about the children and families with whom they will work. Most frequently, this is done through a sensitivitytraining design that brings in speakers from representative groups or through readings of first person narratives. This project stands apart from those models for not only the frequency and intensity of the intervention, but the supportive environment that develops as the students' fragile new understanding emerges. The Personal Doll Project is more closely aligned with a coaching model, inviting the new learning to unfold in a supported context, while still being challenged to grow in new directions. Coaching has proven to be an effective mechanism for in-service teaching (Neuman, 2009). It would seem that it is also a worthy undertaking in the preservice setting as well.

\section{Conclusion}

As classrooms become increasingly diverse, preparing a teaching force with the skills, dispositions and appreciation for working with children whose backgrounds are very different than their own is a necessity. The Persona Doll Project shows the level of reflection and learning that can occur among a culturally similar group of preservice teachers. Strategies such as those used in Persona Doll Project help develop students' knowledge of cultural variation among children and families while also deepening their capacity to reflect on their own experience and bias. They also promote perspective taking and 


\section{Social Studies Research and Practice}

http://www.socstrp.org

advocacy skills through the use of narrative. While the preservice teachers in this project were from culturally similar backgrounds, strategies employed in the Persona Doll Project can benefit any teacher candidate in an Early Childhood Education program.

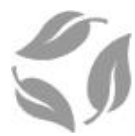

\section{References}

Print Based Resources

Berk, L. E. (1994). Vygotsky's theory: The importance of make-believe play. Young Children, 50(1), 30-39.

Boling, E. C. (2007). "Yeah, but I still don't want to deal with it." Changes in a Teacher Candidate's Conceptions of Inclusion. Teaching and Teacher Education, 16(3), 365387.

Bolton, G. (2006). Narrative writing: reflective enquiry into professional practice. Education Action Research, 14(2), 203-218.

Causey, V. E., Thomas, C. D., \& Armento, B. J. (2000). Cultural diversity is basically a foreign term to me: The challenges of diversity for preservice teacher education. Teaching and Teacher Education, 16(1), 33-45.

Clark, C. Medina, C. (2000). How reading and writing literacy narratives affect preservice teachers' understanding of literacy, pedagogy, and multiculturalism. Journal of Teacher Education, 51(1), 63-76.

Conle, C., Blanchard, D., Burton, K., Higgins, A., Kelly, M., Sullivan, L. \& Tan, J. (2000). The asset of cultural pluralism: An account of crosscultural learning in pre-service teacher education. Teaching and Teacher Education, 16(3), 365-387.

Cowhey, M. (2006). Black Ants and Buddhists: Thinking critically and teaching differently in the primary grades. Portland, ME: Stenhouse.

Derman-Sparks, L. \& Olsen, J. (2010). Anti-Bias education for young children and ourselves. Washington DC: NAEYC.

Doyle, W. \& Carter, K. (2003). Narrative and learning to teach: Implications for teacher-education
The Persona Doll Project is not one that can be prepared once and taught the same way repeatedly. Students bring their own stories, needs and questions. If we are to teach our students as we want them to teach children, we must embrace intensive teaching and learn alongside our students.

curriculum. Journal of Curriculum Studies, 35(2), 129-137.

Edwards, C. P., Logue, M.E. \& Russell, A.S. (1983). Talking with young children about social ideas. Young Children, 39(1), 12-20.

Eisenberg, N. M., Miller, P.A. (1987). The relation of empathy to prosocial and related behaviors. Psychology Bulletin, 101(1), 91-119.

Elbaz-Luwisch, F. (2001). Personal story as passport: Storytelling in border pedagogy. Teaching Education, 12(1), 81-101.

Ford, T. L. \& Dillard, C.B. (1996). Becoming multicultural: A recursive process of self and social construction. Theory into Practice, 35(4), 232-238.

Glasser, B. (1965). The constant comparative method of qualitative analysis, Social Problems, 12(4). California: University of California Press.

Gonzalez, N., Moll, L. C., \& Amanti, C. (2005). Funds of knowledge: Theorizing practices in households, communities, and classrooms. Mahwah, NJ: Lawrence Erlbaum Associates.

Hyun, E. M., Marshall, J. D. (2003). Critical inquiry into emergent-oriented curriculum practice. Journal of Early Childhood Teacher Education, 24(1), 37-50.

Kagan, D. (1992). Professional growth among preservice and beginning teachers. Review of Educational Research, 62, 129-169.

Ladson-Billings, G. (1994). The dreamkeepers: Successful teachers of African American children. San Francisco: Jossey-Bass.

McCall, A. L. (1995). Constructing conceptions of multicultural teaching: Preservice teachers' 


\section{Social Studies Research and Practice \\ http://www.socstrp.org}

life experiences and teacher education. Journal of Teacher Education, 46, 340-350.

McIntosh, P. (1998). White privilege and male privilege: A personal account of coming to see correspondence though word in women's studies. Wellesley MA: Center for Research on Women (ERIC Documentation Reproduction Service No. ED 335262).

Moran, M. J. (2002). Implications for the study and development of inquiry among early childhood preservice teachers: A report from one study. Journal of Early Childhood Teacher Education, 23(1), 39-44.

Munby, H., Russell, T. \& Martin, A .K. (2001). Teachers' knowledge and how it develops. Chicago: Rand McNally.

National Council for the Accreditation of Teacher Educators (2002). Professional standards for the accreditation of schools, colleges, and departments of education. Washington, DC.

Nieto, S. (2009). Language, culture and teaching: Critical perspectives for a new century, $2^{\text {nd }}$ edition. Florence, KY: Routledge.

Nieto, S. (1998). From claiming hegemony to sharing space: Creating community in multicultural course. In R. Chavez-Chavez, \& J. O'Donnell (Eds.), Speaking the unpleasant: The politics of (non) engagement in the multicultural education terrain (pp. 16-31). Albany: State University of New York Press.

Neuman, S.B. (2009). The impact of professional development and coaching on early language and literacy instructional practices. American
Educational Research Journal, 46(2), 532566.

Petrash, J. (2002). Understanding waldorf education: teaching from the inside out. Lewisville, NC: Gryphon House.

Paley, V.G. (1996). Kwanzaa and me: A teacher's story. Cambridge, MA: Harvard Universtiy Press.

Schussler, D.L., Stooksberry, L.M., \& Bercaw, L.A. (2010). Understanding teacher candidate dispositions: Reflecting to build selfawareness. Journal of Teacher Education 61(4), 350-363.

Selman, R.L. (1980). The growth of interpersonal understanding: developmental and clinical analyses. New York, NY: Academic Press.

Sleeter, C.E. (1995). White preservice students and multicultural coursework. In J. M. Larkin \& C.E. Sleeter (Eds.), Developing multicultural teacher education curricula, (pp. 17-29). Albany, NY: SUNY Press.

Sleeter, C.E. (2001). Preparing teachers for culturally diverse schools. Journal of Teacher Education, 52(2), 94-106.

Starting small (1997). Montgomery, AL: Southern Poverty Law Center.

Whitney, T. (2002). Kids like us: Using persona dolls in the classroom. St. Paul, MN: Redleaf.

$\mathrm{Xu}, \mathrm{H}$. (2000). Preservice teachers integrate understanding of diversity into literacy instruction: An adaptation of the ABC's model. Journal of Teacher Education, 51(2), 135-142. 


\section{Appendix}

Descriptions of Dolls

\begin{tabular}{|l|l|}
\hline Doll & Characteristics \\
\hline Janella & $\begin{array}{l}\text { Age 6. African American. She shows prodigious talents in math and } \\
\text { special awareness especially building with blocks and legos. She lives } \\
\text { cathedrals and aqueducts are not appreciated by her peers. }\end{array}$ \\
\hline Raven & $\begin{array}{l}\text { Age 5. Native American Penobscot. Father is on the tribal council. } \\
\text { recently closed and is unemployed. Raven loves art and stories. Raven } \\
\text { has severe allergies to nuts, wheat and soy. }\end{array}$ \\
\hline
\end{tabular}




\begin{tabular}{|l|l|}
\hline Carlos & $\begin{array}{l}\text { Age 7. Mexican American } \\
\text { His mother, one of } 10 \text { children in a migrant family wants her children to } \\
\text { have the educational advantages she did not have. She works as an } \\
\text { assistant in the Migrant Head Start program. His mother decided to } \\
\text { stay in Maine for Carlos' treatment and his father continues to travel } \\
\text { the migrant stream along with many aunts and uncles to harvest fruit. } \\
\text { He recently completed treatment for childhood leukemia and is back in } \\
\text { school. He lives with 2 older brothers, and his mother. } \\
\text { Spanish is home language. He loves to play cards and soccer. } \\
\text { Age 6. Mother a surgeon, father an orthodontist, } 2 \text { older sisters, } \\
\text { parents are divorcing. Nanny lives with them but they have trouble } \\
\text { keeping a nanny. The parents have joint custody. Elizabeth's parents } \\
\text { are Jewish. } \\
\text { His parents are learning English. He is Muslim and speaks Somali as his } \\
\text { home language and is learning English at school. He is very proud of his } \\
\text { heritage. He loves to draw. }\end{array}$ \\
\hline Omar in this country for 3 years and lives with his parents and 2 sisters. \\
His
\end{tabular}




\begin{tabular}{|c|c|}
\hline Mei & $\begin{array}{l}\text { Age 8. Adopted from China when she was a baby. } \\
\text { Her parents are teachers. She lives with her two older brothers and her } \\
\text { younger brother, who has special needs. Mei loves to sing and tell } \\
\text { stories. She moved to Maine last year and misses her grandmother. }\end{array}$ \\
\hline Billy & $\begin{array}{l}\text { Age 5. Lives with his parents and baby brother in a trailer } 15 \text { miles from } \\
\text { town. He loves cars and has a special love of NASCAR. His Dad drives a } \\
\text { delivery truck and his mom stays home with the children. He was } \\
\text { recently diagnosed with Asperger's syndrome. His family is Jehovah } \\
\text { Witness. }\end{array}$ \\
\hline Damien & $\begin{array}{l}\text { Age 5. Lives with his father who works for the Post Office. They live in a } \\
\text { second floor apartment with elderly people downstairs, people who do } \\
\text { not like noise. His mother died in a car accident when he was one. He } \\
\text { has fetal alcohol syndrome. He loves animals, especially dogs and is } \\
\text { very close to his maternal grandparents who live nearby. His Dad is a } \\
\text { recovering alcoholic who tries to work his meeting schedule around } \\
\text { Damien's but is still out several nights/week. }\end{array}$ \\
\hline Toby & $\begin{array}{l}\text { Toby is a 5-year-old African American child who lives with his sister in a } \\
\text { foster home. His parents struggle with active drug addictions and he } \\
\text { lived with his grandmother until her health failed. He is angry often but } \\
\text { children like him. He loves any kind of active play. He has lots of energy } \\
\text { and hates to sit still. Teachers wonder about him having ADHD or ODD. }\end{array}$ \\
\hline
\end{tabular}




\begin{tabular}{|c|c|}
\hline Heather & $\begin{array}{l}\text { Heather is } 7 . \text { She was born when her mother was } 16 \text { and her } \\
\text { grandmother was } 32 . \text { Her mother is in school, trying to break the } \\
\text { generations of poverty the family has experienced. Heather lives with } \\
\text { her mother in a subsidized apartment. She reads chapter books in } \\
\text { kindergarten and loves to dance. She has frequent ear infections. }\end{array}$ \\
\hline Pierre & $\begin{array}{l}\text { Pierre is in second grade. He lives with his parents and older brother. } \\
\text { He moved from Northern Maine and speaks French at home. He likes to } \\
\text { play chess, tell jokes, and loves snakes and salamanders. He makes } \\
\text { people laugh. Sometimes he says very mean things and uses bad } \\
\text { language. He was recently diagnosed with Tourettes Syndrome. }\end{array}$ \\
\hline Josie & $\begin{array}{l}\text { Josie lives with her mother and her stepfather in an apartment. On } \\
\text { weekends, her stepfather's } 10 \text { and 12-year old sons live with them. } \\
\text { Josie is deaf and has been recommended for a cochlear implant. Her } \\
\text { maternal grandmother who is also deaf fiercely opposes it. She is fluent } \\
\text { in sign language and has an interpreter in school }\end{array}$ \\
\hline Ben & $\begin{array}{l}\text { Ben is five years old. He had a hard adjustment to kindergarten because } \\
\text { he had never been away from home. He lives with his parents, sister } \\
\text { and } 3 \text { dogs in a trailer. In winter, the pipes freeze and the family must } \\
\text { carry in water. Ben comes to school dirty and children tease him for } \\
\text { smelling bad. Ben is quite withdrawn and cries easily. }\end{array}$ \\
\hline
\end{tabular}




\begin{tabular}{|l|l|}
\hline David & $\begin{array}{l}\text { David is 6. He lives with his father and older sister. David loves cooking } \\
\text { magazines and TV shows and loves watching track and field events. He } \\
\text { is very affectionate. Sometimes though, people don't appreciate his } \\
\text { hugs. David has Down's Syndrome. }\end{array}$ \\
\hline Harvey & $\begin{array}{l}\text { Harvey is } 6 . \text { He loves video games, t-ball, dinosaurs and space. He lives } \\
\text { family his parents and older brother. His father is in the military and the }\end{array}$ \\
\hline Lilly & $\begin{array}{l}\text { Lilly is 5. She and her mother recently moved into her grandmother's } \\
\text { small apartment because of domestic violence. Lilly loves to play dress } \\
\text { up and house but has a hard time controlling her anger and can } \\
\text { become out of control and have tantrums. Lilly has bad dreams and } \\
\text { often comes to school tired. Lilly's father is allowed no contact with her } \\
\text { mother or her. }\end{array}$ \\
\hline Michael & $\begin{array}{l}\text { Michael is } 6 \text { years old. He lives with his mother and her new boyfriend } \\
\text { after being fired from his job. Michael has difficulty staying on task and }\end{array}$ \\
\hline
\end{tabular}




\begin{tabular}{|c|c|}
\hline Jason & $\begin{array}{l}\text { Jason is } 5 \text { years old. He takes medication for Juvenile Rheumatoid } \\
\text { Arthritis that affects his growth. Children tend to treat him as a much } \\
\text { younger child though he is cognitively at age-level. It is difficult to get } \\
\text { up and down from the floor. He resists getting dressed and insists on } \\
\text { wearing as few clothes as possible. He has a wonderful sense of humor } \\
\text { and can make others laugh. }\end{array}$ \\
\hline Alicia & $\begin{array}{l}\text { Alicia is } 6 \text { years old. She lives in Bangor in the same house where her } \\
\text { mother grew up. She lives with her mother, father, an older brother, a } \\
\text { younger sister and her grandmother. Her grandmother has lung cancer } \\
\text { and her mother cares for her at home. Alicia's father is in the Military } \\
\text { and is about to leave for his second tour in Afghanistan. }\end{array}$ \\
\hline
\end{tabular}

\section{ABOUT AUTHOR}

Mary Ellin Logue, Associate Professor of Early Childhood Education at the University of Maine. Her research interests include creating environmental interventions to increase children's school success, teacher education, and promoting social development and learning through inclusive, anti-bias education. Email: mary.logue@maine.edu

Susan Bennett-Armistead, Correll Professor of Early Literacy at the University of Maine. Dr. BennettArmistead writes and speaks extensively about early literacy and teacher education. She regularly serves as a community consultant for the Persona Doll Project.

Soo-Joung Kim, graduate student in early literacy, is a consultant to the Persona Doll Project. She is a guest speaker in class where she helps students understand about cultural differences and potential conflicts between families and teachers. 
Social Studies Research and Practice

http://www.socstrp.org 